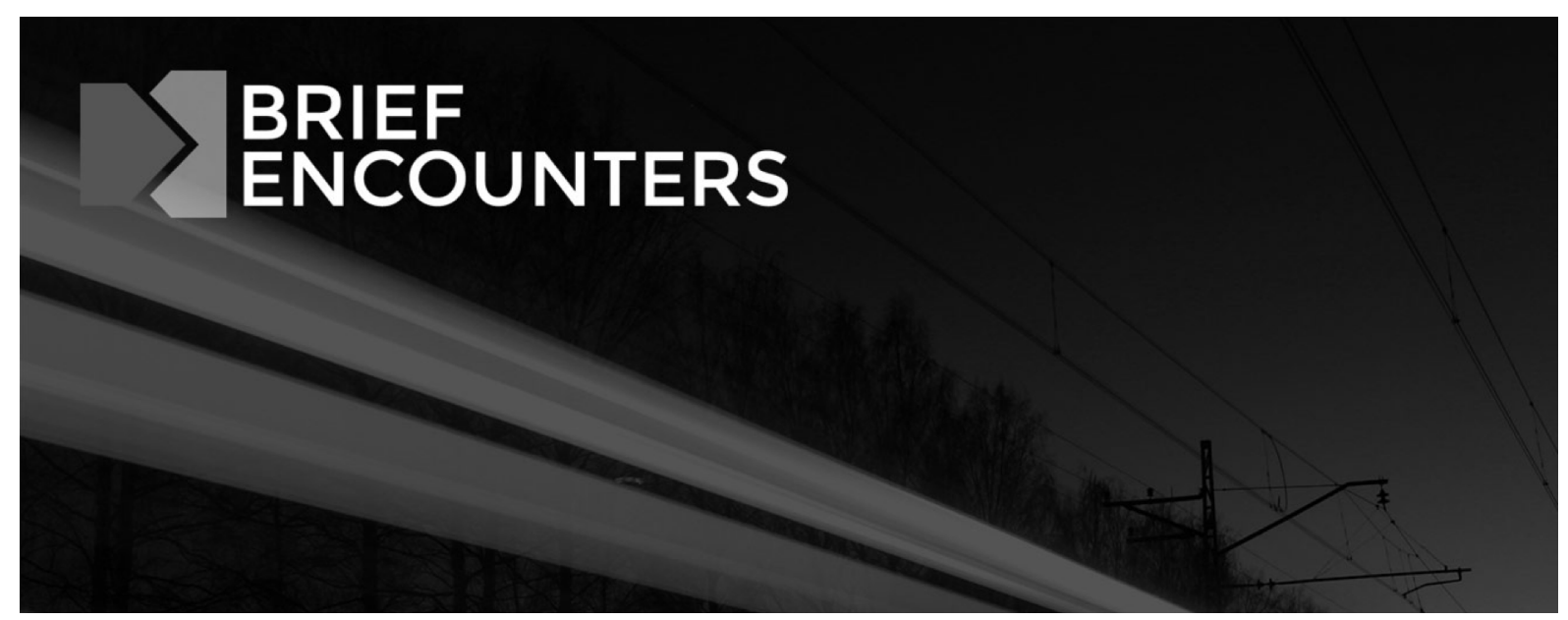

ISSN 2514-0612

Journal homepage: http://briefencounters-journal.co.uk/BE

Comfort through 'the lively Word of God': Katherine Willoughby and the Protestant Funeral Monument

Author(s): Eva Lauenstein

Email: elauen01@mail.bbk.ac.uk

Source: Brief Encounters Vol.1, No. 1 (Feb 2017)

URL: http://briefencounters-journal.co.uk/BE/article/view/25/

DOI: http://dx.doi.org/10.24134/be.v1i1.25

(C) Eva Lauenstein, 2017

License (open-access): This is an open-access article distributed under the terms of the Creative Commons Attribution License 4.0, which permits unrestricted use, distribution, and reproduction in any medium, provided the original work is properly cited. No warranty, express or implied, is given. Nor is any representation made that the contents will be complete or accurate or up to date. The publisher shall not be liable for any actions, claims, proceedings, demand or costs or damages whatsoever or howsoever caused arising directly or indirectly in connection with or arising out of the use of this material.

Brief Encounters is an open access journal that supports the dissemination of knowledge to a global readership. All articles are free to read and accessible to all with no registration required. For more information please visit our journal homepage: http://briefencounters-journal.co.uk/BE. 


\section{Comfort through 'the lively Word of God': \\ Katherine Willoughby and the Protestant Funeral Monument}

\section{Eva Lauenstein}

The death of Katherine Willoughby, Duchess of Suffolk in 1580 was marked by the erection of a lavish funeral monument at Spilsby in Lincolnshire (see Fig. 1). ${ }^{1}$ The second panel of six on its west-facing side can be translated from the Latin as follows:

We know that our Redeemer lives, and we believe that we shall rise again out of the dust and though after our skin worms destroy our bodies, yet shall we see God in our flesh, and not another. ${ }^{2}$

What does the use of such biblical scripture, viewed through the monument's material and spatial presence in the church building, disclose about the role of the places for the dead in establishing and maintaining church practices and ritual during the formative years of the Reformation? The monument cites a well-known passage from Job 19 but by deviating from its most readily available source, the Vulgate, as well as several major English language Bible translations and the Book of Common Prayer, the passage evidences a textual engagement with scripture associated with a Protestant patron's commitment to a critical approach to the written word of God. ${ }^{3}$ However, by making use of no less than seventeen predominantly Latin texts on the tomb, the design goes against the grain of a protestant dismissal of the Latin in devotional reading and writing practices, as stressed by influential Henrician divine Thomas Becon, who admonished the 'mu[m]bled' word of God by the 'Papistes' in the 'latin to[n]ge',

\footnotetext{
1 The sculptor of the tomb is unknown, though a surviving household account book (1581) from Katherine Willoughby and Richard Bertie's residence at Grimsthorpe identifies a certain Thomas Goodlord as 'the maker of the tombe'. Lincoln, Lincolnshire Archives, 10-ANC/317/1.

2 Job 19.25-26. The inscription reads: 'Novimus quod redemptor noster vivit, et credimus posteriorem super pulverem resurrectionem, et postquam vermes confoderint nostra cadavera, tamen visuros esse Deum carne nostra, et non aliena'.

3 The passage was additionally compared to the Douay-Rheims edition of the Book of Job, the Great Bible (1539), the Bishops' Bible (1568) and the Geneva Bible (1560).
} 

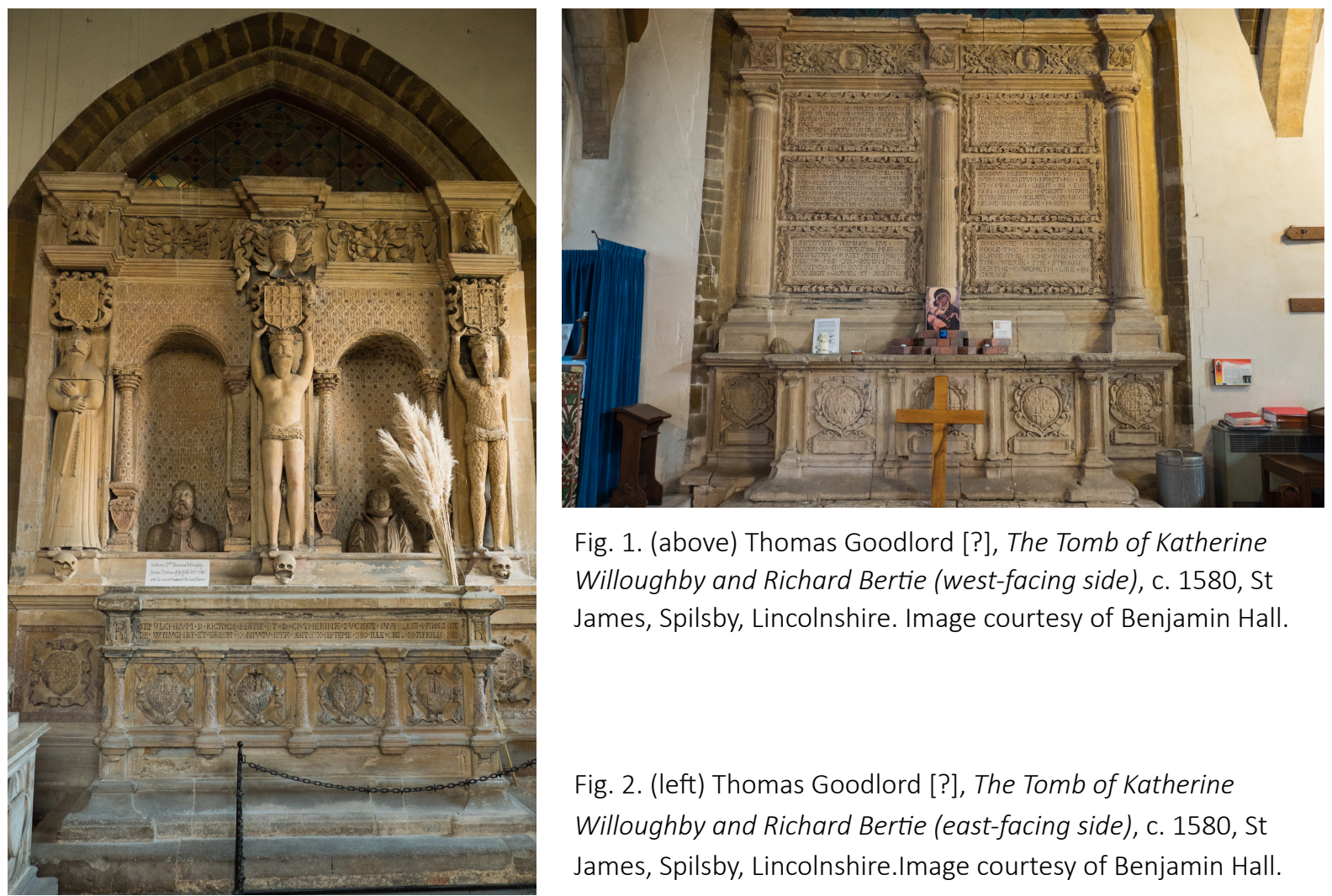

Fig. 1. (above) Thomas Goodlord [?], The Tomb of Katherine Willoughby and Richard Bertie (west-facing side), c. 1580, St James, Spilsby, Lincolnshire. Image courtesy of Benjamin Hall.

Fig. 2. (left) Thomas Goodlord [?], The Tomb of Katherine Willoughby and Richard Bertie (east-facing side), c. 1580, St James, Spilsby, Lincolnshire.Image courtesy of Benjamin Hall.

preferring instead 'the mother tounge, that the Idiote and vnlearned may vnderstande it and be edifyed.' ${ }^{4}$ Additionally, the monument's design and placement equally raises questions about its intended audience and function within the sixteenth-century fabric of the parish church. Filling in the entire space of the arch leading into the attendant chapel to the north of the chancel, the tomb, like a rood screen, seals the chapel space beyond from the nave. On this west-facing, nave-oriented side, fluted ionic columns divide the blank canvas of the construction into two spaces filled with the six panels reserved for the above-mentioned texts. The short altar-like chest that projects from its lower portion, with its detailed heraldry, is the only indication of the identity of the deceased. The monument's east-facing side projecting into the chapel space, in contrast, reveals a more lavishly individualised composition. This side's large projecting tomb chest, surmounted by the carved figures of a monk and two wild men, focuses the viewer's attention on the two centrally placed alabaster

\footnotetext{
${ }^{4}$ Thomas Becon, The Castell of Comforte (London: John Day, 1549), sig. F5r.
} 
busts of Katherine Willoughby, and her second husband Richard Bertie (see Fig. 2). ${ }^{5}$ Choosing to obscure from view the lavish busts and carved figures, all indicative of the deceased's identity and lineage, and instead foregrounding the biblical word on its visually accessible side, highlights the potential of the monument in articulating a public and communal function beyond its role as a commemorative object.

This article argues that in addition to a commemorative function, Katherine Willoughby's tomb, in its choice of text and spatial arrangement, expresses the monument's role in the construction of communal protestant church space. By comparing the Willoughby monument to examples of contemporary tombs of influential protestant families who took pains to commemorate individuals that had, through the good fortune of a long life, experienced the transformation of English devotional practice from Henry VIII's Act of Supremacy in 1534 to the Elizabethan Religious Settlement (1559) and beyond, the article investigates the way in which the funerary monument formed a spatial marker in a constructive re-articulation of old church space through their function as 'presencing mechanisms'. ${ }^{6}$ Emphasising the pragmatic nature of this change equally sheds new light on the continuing use of Latin scripture, which found increasing tolerance in the Elizabethan via media, that officially sanctioned reading, 'either in Latin or in English', through the Elizabethan Injunctions (1559) as part of an effort to 'discourage no man [...] from reading any part of the Bible'.7

At the centre of the Lincolnshire Reformation, Katherine Willoughby (1519-1580) combined political status as a member of the Henrician court with a place among notable Evangelical reformers, including Hugh Latimer, Thomas Becon and Katherine Parr. Through ties

\footnotetext{
${ }^{5}$ Nikolaus Pevsner and John Harris, Lincolnshire, The Buildings of England (Harmondsworth: Penguin, 1964), p. 374. The earliest account of the monument and its placement was penned by antiquarian Gervase Holles. See Gervase Holes, Lincolnshire Church Notes made by Gervase Holles A. D. 1634 to A. D. 1642, ed. by R. E. G. Cole (Lincoln: W. K. Morton \& Sons, 1911), p. 85.

${ }^{6}$ Simon Roffey, Chantry Chapels and Medieval Strategies for the Afterlife (Stroud: Tempus, 2008), p. 20; Pamela Graves, The Form and Fabric of Belief: The Archaeology of Lay Experience in Medieval Norfolk and Devon, BAR British Series 311 (Oxford: Archaeopress, 2000), p. 13.

7 'Elizabethan Injunctions, 1559', in Documents of the English Reformation, ed. by Gerald Bray, Library of Ecclesiastical History (Cambridge: James Clarke \& Co, 1994), pp. 335-48 (p. 337).
} 
into the textual networks of these reformist figures, as traced by Melissa Franklin-Harkrider and Alec Ryrie, Willoughby was at the forefront of a national re-articulation of scripture for public consumption throughout the theological developments under Henry VIII, Edward VI and Elizabeth I, and its regional impact in the local communities of Lincolnshire. ${ }^{8}$ Indeed, with the above-mentioned passage most closely resembling the Geneva and Bishops' Bible translations, the inscription echoes the influence of these particular versions of scripture that, through their inclusion of extensive notes and cross-references in the case of the former, and the ready availability and image heavy accessibility of the latter, encouraged an active and critical reading practice. The tomb's inscription, however, deviates even from its closest comparative texts by altering Job's first person singular into the first person plural, indicating that beyond an intertextual reading of scripture, Willoughby equally engaged in the alteration of the text to suit a particular purpose; in which the ' $I$ ' of the Book of Job required modification to the 'we' of the monument's viewership. In context, this use of monuments 'as sites for writing', as fittingly expressed by Patricia Phillippy, reminds us that the textuality at play is really part of a larger interrelationship between text and the materiality of the monument, the church it inhabits, and the audience to which it speaks. ${ }^{9}$

Spilsby's St James and its attendant chapel, once home to a chantry college dedicated to the Holy Trinity and established by John Willoughby in 1347, was one of several established burial places of some of Katherine's most notable ancestors. ${ }^{10}$ The two northernmost arcades formed the core of the fourteenth-century church, with the chantry occupying the northern nave and the chapel by the time of the imposition of the Edwardian Chantries Act (1548). ${ }^{11}$ As late as 1503 William Willoughby bequeathed $£ 200$ to the college, and it was on the eve of the

\footnotetext{
${ }^{8}$ Melissa Franklin-Harkrider, Women, Reform and Community in Early Modern England: Katherine Willoughby, Duchess of Suffolk, and Lincolnshire's Godly Aristocracy, 1519-1580 (Woodbridge: Boydell Press, 2008), p. 46; Alec Ryrie, The Gospel and Henry VIII: Evangelicals in the Early English Reformation (Cambridge: Cambridge University Press, 2003), p. 195.

9 Patricia Phillippy, “"Monumental Circles” and Material Culture in Early Modern England', Early Modern Women, 4 (2009), 139-47 (p. 141).

10 Nikolaus Pevsner and John Harris, Lincolnshire, The Buildings of England (Harmondsworth: Penguin, 1964), pp. 373-74.

11 Harry Cotton Smith, The Town of Sir John Franklin: A History of Spilsby in Lincolnshire, with Notes on Eresby and Other Places Connected Therewith (Spilsby: The Spilsby Printing Company, 1892), p. 47.
} 
Henrician Reformation, in 1529, when money was set aside for the addition of the tower at the westernmost end of the building. ${ }^{12}$ It is therefore unsurprising to find that the chantry space preoccupied Katherine only roughly twenty years after the last major investment by the Willoughby family in the parish church. Writing to future Secretary of State William Cecil in 1549, Willoughby expressed her 'desire to purchase Spilsby chantry' through her willingness to 'labour [...] friends with private letters', including the hope for the influential Cecil's advice, without which she feared she 'must proceed blindly'.13 Her wish to purchase the chantry, contemporaneous with the confiscation of such intercessory institutions, was therefore likely a direct result of the large scale re-purposing of what was considered contested and liturgically and ritually redundant space. Indeed it is conceivable that Willoughby, mirroring the rhetoric of the Chantries Act, sought to rectify the past's 'Blindness and Ignorance' by the recovery of the chantry and repurposing in the service of 'good and godly Uses'. ${ }^{14}$

Willoughby acquired Spilsby chantry, but her exile throughout the reign of Queen Mary I would delay any plans for the construction of a monument. Thus it is most likely by the early years of the reign of Elizabeth I, and Willoughby's return to Lincolnshire, that work on her monument was begun. Through situating both text and object, the monument expresses a change in a spatial understanding of the church highlighted in the Elizabethan Injunctions stipulating that people,

shall not from henceforth in any parish church, at any time use any procession about the church or churchyard, or other place, but immediately before high mass the priest, with others of the choir, shall kneel in the midst of the church and sing or say, plainly and distinctly, the Litany [...] and in cathedral or collegiate churches the same shall be done. ${ }^{15}$

\footnotetext{
12 Michael Hicks, 'Willoughby family (per. c.1300-1523)', in Oxford Dictionary of National Biography, online edn, January 2008 (Oxford: Oxford University Press, 2004) <http://www.oxforddnb.com/view/article/52801> [accessed 5 May 2016].

${ }^{13} \mathrm{Kew}$, The National Archives, State Papers Domestic Edward VI, 10/10/8.

${ }^{14}$ The statutes at large, of England and of Great Britain: from Magna Carta to the union of the kingdoms of Great Britain and Ireland, ed. by Thomas Edlyne Tomlins and John Raithby, 20 vols (London: G. Eyre and A. Strahan, 1811), III, p. 500.

15 'Elizabethan Injunctions, 1559', pp. 339-40.
} 


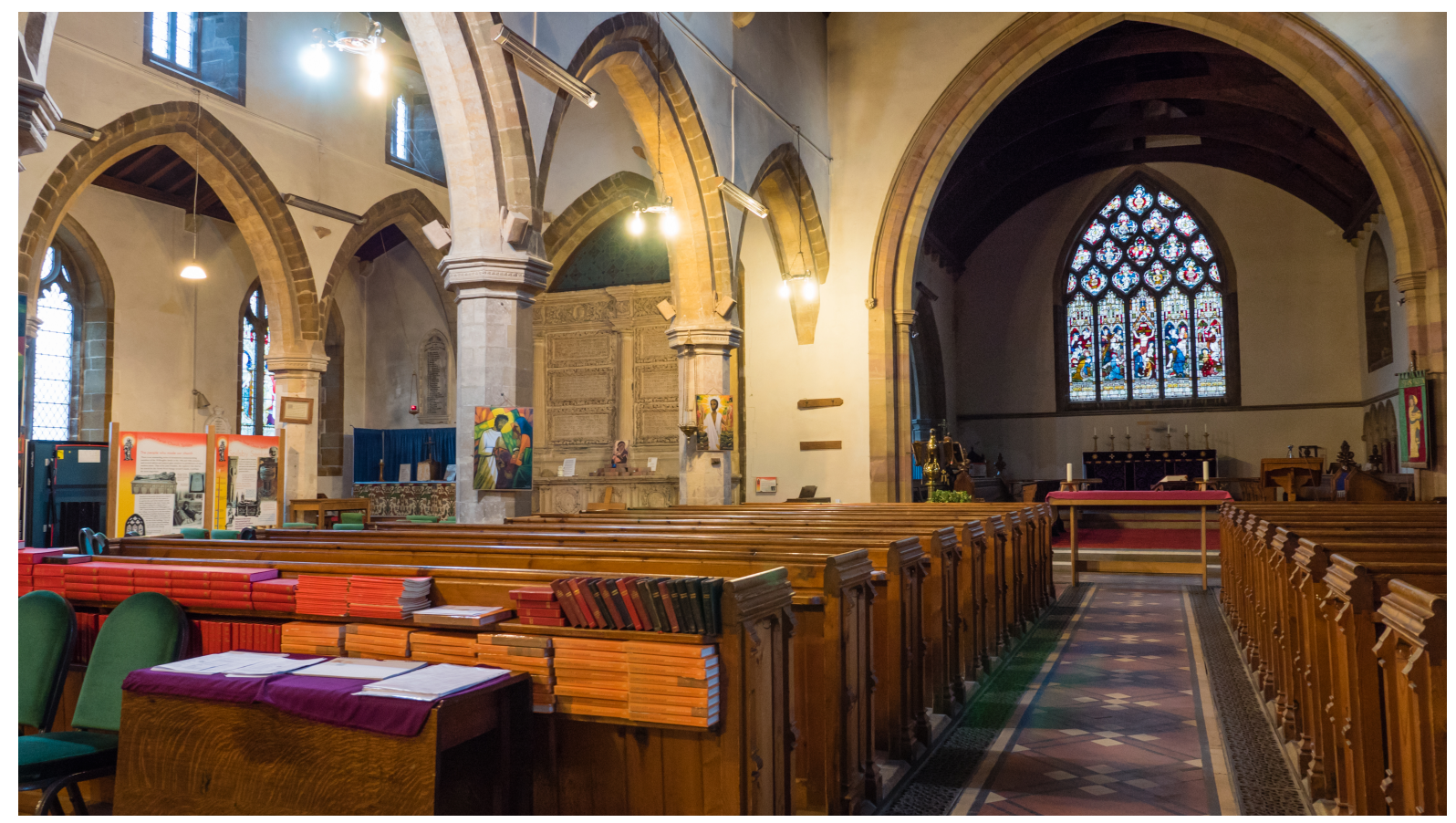

Fig. 3. The parish church of St James viewed from the nave facing north-east. St James, Spilsby, Lincolnshire. Image courtesy of Benjamin Hall.

Emphasising the nave as the focal point of the devotional practices of the Elizabethan church, the Injunctions highlight the levelling of the spatial hierarchies in the church fabric. With the priest and all attendants 'in the midst of the church', and out of the elevated chancel, the distance between the clergy and the congregation is visually diminished. Prohibiting processions and ritual movement, making special mention of such practices 'in cathedral or collegiate churches' actively shifts emphasis away from the now redundant secondary altars, chantry spaces, and the network of attendant sites dedicated to the intercessory economy of the latter Middle Ages. Instead, to avoid 'contention and strife' through the 'challenging of places' that accompanied ritual procession and ancillary sites of devotion, the Injunctions articulate the new static nature of the congregation in the nave of the church. It is explicitly the breaking down of clerical and secular hierarchy that form the core rationale behind the restriction of movement as 'walking in the church' without 'just and urgent cause' is granted to 'no manner of persons', regardless of their status. ${ }^{16}$

\footnotetext{
16 Ibid., pp. 339-40.
} 
Contextualising the way church space is treated in the Injunctions, the Willoughby monument's choice of inscription, most easily read from among the pews of the nave, and its physical 'intrusion' into an established processional route thus allows us to read the tomb as an active participant in the articulation of a nave-oriented Reformed church space (see Fig. 3). Erasing the sight line to the secondary altar of the chantry, the tomb marks a spatial and physical break of the bond between the congregation and the reciprocal benefits of intercessory prayer. Furthermore, by blocking up the northern aisle's passage into the chancel through the chantry, the monument obstructs the mass's often circular processional route leading the participants through the southern and the northern naves. ${ }^{17}$ The tomb thus acts as a physical boundary, but one which stresses through its very materiality the abandonment of the intercessory economy, as well as the pre-Reformation's most central ritual, the Eucharist.

The passage of Job, then, gives established authority to a Protestant iteration of a text by adapting the Geneva and Bishops' Bibles into the Latin, visually reflecting the adaptation of old church space for new purposes and thus contributing to the re-formulation of redundant ritual space into an environment of communal evangelical worship. The first person plural, the 'we' of the monumental inscription thus reflects the levelling of church spaces, the body of Job read not in its individuality, but transformed into 'our bodies', the collective body of the church. Job's individual theological sin, born of sixth century BC Judean orthodoxy and his rebellion against undeserved suffering, is transformed into a contemporary and collective narrative of a reformist rectification of a collective sin born of the orthodoxy of the preReformation church. Willoughby thus transforms Job's reliance on the 'sufficiency of grace' into an Evangelical understanding of a justification through faith, expressing a hopeful Protestant understanding of the triumph of a loving God over death and despair. ${ }^{18}$

\footnotetext{
17 Pamela Graves, 'Social Space in the English Medieval Parish Church', in Anthony Giddens: Critical Assessments, ed. by Christopher G. A. Bryant and David Jary, 4 vols (London: Routledge, 1997), IV, pp. 262-88 (p. 272).

${ }^{18}$ Samuel Terrien, 'Job: Introduction', in The Interpreter's Bible: The Holy Scriptures in the King James and Revised Standard Versions with General Articles and Introduction, Exegesis, Exposition for Each Book of the Bible, ed. by George Arthur Buttick, 12 vols (New York: Abingdon Press, 1954), III, pp. 877-905 (pp. 897-99).
} 
A monument that equally forms a protestant 'intrusion' into church space in order to stress the levelling of spatial hierarchy is the tomb of William Belasyse (1524-1604) by Thomas Browne in St Michael, Coxwold. ${ }^{19} \mathrm{~A}$ large standing wall monument, lavishly decorated with obelisks and heraldry, the Belasyse tomb is a fine example of what Peter Sherlock identifies as 'the dominance of lineage as a theme in the motivation behind early modern monuments. ${ }^{20}$ With the large protruding tomb chest displaying the recumbent effigies of William and his wife surmounting relief figures of three sons, the tomb visually weaves together a narrative of heredity. While the tomb certainly takes pains in constructing 'family fictions', its use of numerous biblical quotations in Latin, in conjunction with its placement suggests that the monument played a role in the construction of church ritual. ${ }^{21}$ This is made evident by a Latin inscription based on Philippians 1.23 that directly surmounts the effigies. As a royally approved Latin prayer in The Preces Privatæ (1564), which reads 'Cupio dissolvi, et esse cum Christo' [I desire to depart and be with Christ], Belasyse follows closely the Elizabethan model of Protestantism under which himself and his father had found both wealth and status. ${ }^{22}$ The monument, however, changes the Latin locution subtly from the appearance of the passage in Preces Privatæ, as well as the Vulgate Bible. ${ }^{23}$ Reading 'Cupio Dissolvi et esse in Christo' [I desire to depart and be one with Christ], Belasyse stresses his complete bodily and spiritual consolidation with Christ, a change that becomes significant with a consideration of the monument's positioning.

The tomb, located on the north wall in the east end of the chancel makes its writing most easily read throughout the communion service, by the time of the Elizabethan

\footnotetext{
${ }^{19}$ Nikolaus Pevsner, Yorkshire: The North Riding, The Buildings of England (Harmondsworth: Penguin, 1966), p. 128.

20 Peter Sherlock, Monuments and Memory in Early Modern England (Aldershot: Ashgate, 2008), p. 19.

21 ibid., p. 17.

22 Christine M. Newman, 'Bellasis family (per. c.1500-1653)', in Oxford Dictionary of National Biography, online edn, January 2008 (Oxford: Oxford University Press, 2004) <http://www.oxforddnb.com/view/article/71863> [accessed 1 August 2016]; Private Prayers, Put Forth by Authority during the Reign of Queen Elizabeth, ed. by Rev. William Keatinge Clay (Cambridge: Cambridge University Press, 1851), p. 360.

${ }^{23}$ Philippians 1.23 in the Vulgate reads as follows: 'Coarctor autem e duobus: desiderium habens dissolvi, et esse cum Christo, multo magis melius'.
} 
Injunctions taking place in the upper nave or chancel space with the table facing east to west. With the priest commonly occupying the north side of the table, the monument would have functioned as the constant backdrop to the ritual. ${ }^{24}$ Framing the moment of the communion service, then, the inscription textually reflects the diminished physical distance between the congregation and Christ, as expressed in the words spoken by the priest throughout the Holy Communion and contained in the Book of Common Prayer; 'for then we spiritually eate the fleshe of Christ, and drincke his blonde, then we dwell in Christe and Christe in us, we be one wyth Christ, and Christe with us'.25 As in the case of the Willoughby monument, the remodelling of Latin scripture and the placement of both text and tomb reflect and perpetuate a new understanding of old church space, in which the focus on the nave, as well as the regular access of the community into the chancel space has become part of church ritual.

Using scripture on the commemorative object to emphasise the nave as the centre of devotional practice was equally employed by more radical Protestant communities and evident in the monument in dedication of several members of the Knightley family in the church of St Mary in Fawsley. ${ }^{26} \mathrm{~A}$ large standing wall monument commemorating Sir Richard (d. 1615), Mary (d. 1573) and Sir Valentine Knightley (d. 1566) by an unknown artist, the construction's central focus is a highly elevated sarcophagus decorated with putti and supported by two praying caryatids. Immediately below it, and supported by long brackets lies a small effigy. Unlike the Belasyse monument, the tomb is not populated by representations of family members, but instead reserves large portions of the space on either side of the effigy for lengthy panels of inscriptional writing. Among three biblical inscriptions,

\footnotetext{
24 'Elizabethan Injunctions, 1559', p. 347; 'The Book of Common Prayer, 1559', in The Book of Common Prayer: The Texts of 1549, 1559, and 1662, ed. by Brian Cummings (Oxford: Oxford University Press, 2011), pp. 99-181 (p. 124). A contemporary account states that the table was orientated 'east and west, and the preast on the northe syde, his face turnyde towarde the sowth.' A. G. Dickens and Robert Parkyn, 'Robert Parkyn's Narrative of the Reformation', English Historical Review, 62.242 (1947), 58-83 <https://doi.org/10.1093/ehr/LXII.CCXLII.58> [accessed 9 January 2017] (pp. 74-75).

25 'The Book of Common Prayer, 1559', p. 132.

${ }^{26}$ The earliest antiquarian mention of the monument's position is by John Bridges. See John Bridges, The history and antiquities of Northamptonshire. Compiled from the manuscript collections of the Late Learned Antiquary John Bridges, Esq. By the Rev. Peter Whalley, 2 vols (Oxford: T. Payne, 1791), I, p. 69.
} 
the two located in the lower left and right portion of the monument are taken from the Book of Proverbs. ${ }^{27}$ Likely built sometime after the death of Sir Richard Knightley (1533-1615), who oversaw the printing of the Marprelate Tracts (1588), it is unsurprising to find that this monument is a 'biblically justified memorial to the elect dead'. ${ }^{28}$ Located in the east end of the north aisle, the tomb takes the place in immediate proximity to the location commonly reserved for the pulpit in the transept. ${ }^{29}$ As stressed by Andrew Spicer, the decreased frequency of the administration of Lord's Supper, particularly in Reformed and Puritan communities such as the ones perpetuated by Knightley, meant that the 'chancel or choir had essentially become redundant' in favour of the pulpit as the focal point of church life. ${ }^{30}$ This had the effect of making the north-eastern end of the nave, nearest the pulpit, the most desirable space throughout services. ${ }^{31}$ With the monument's placement in mind, the emphasis on the Book of Proverbs thus suggests its intertextual relationship with the puritan sermons of the rector of Fawsley, John Dod (1550-1645). Dod, together with his co-author Robert Cleaver, took a particular interest in the study of this book of the Bible, as evidenced by several publications. ${ }^{32}$ According to one of these texts, $A$ briefe explanation of the whole booke of the Prouerbs (1615), the use of Proverbs allows 'Ministers to be fruitfull Preachers', while equally providing 'wholesome meditation to the minde' of 'priuate persons'. ${ }^{33}$ The explanation of both passages found on the Knightley tomb express precisely this relationship

\footnotetext{
27 Inscriptions read: 'The liberal Person shall have plenty, and he that watereth shall also have raine' (Proverbs 11.25) and 'The Memorial of the juste shall be Blessed, but the name of the Wicked shall rot' (Proverbs 10.7). Both passages are most reminiscent of the Geneva Bible.

${ }^{28}$ The History of Parliament, The House of Commons 1558-1603, ed. by P. W. Hasler, 3 vols (London: Her Majesty's Stationery Office, 1981), II, pp. 405-6; Sherlock, p. 207.

29 'Elizabethan Injunctions, 1559', p. 341. The 1636 account of St Mary's in Cambridge states that 'the service pulpit is set up in the midst [of the nave], a good distance below the chancel'. As transcribed in Robert Whiting, The Reformation of the English Parish Church (Cambridge: Cambridge University Press, 2010), p. 178.

30 Andrew Spicer, 'Architecture', in The Reformation World, ed. by Andrew Pettegree (London: Routledge, 2000), pp. 505-20 (p. 513).

${ }^{31}$ Robert Tittler, 'Political Culture and the Built Environment of the English Country Town, c.1540-1620', in Tudor Political Culture, ed. by Dale Hoak (Cambridge: Cambridge University Press, 1995), pp. 133-56 (p. 144).

32 John Dod, Bathshebaes instructions to her sonne Lemuel containing a fruitfull and plaine exposition of the last chapter of the Prouerbs. [...] (London: John Beale, 1614); Robert Cleaver and John Dod, A briefe explanation of the whole booke of the Prouerbs of Salomon (London: Felix Kyngston, 1615).

${ }^{33}$ Cleaver and Dod, sig. A3v.
} 
between inwardness and the integral role of spreading the word of God. Thus, the lower left panel containing Proverbs 10.7 articulates the righteousness of the 'semi separatist' congregation 'albeit for a time, through slanders, columniations, and scoffes, they are among the sonnes of Belial'. However, it is through the knowledge of their righteousness that 'no reports, or imputations, no iests or derision can make them contemptible'. ${ }^{34}$ The panel to its right containing Proverbs 11.25, addresses the need for the perpetuation and spread of the word of God, as wealth, both financial and of the spirit is likened to a 'wel-spring', in which one receives 'as much water inwardly, as they send foorth outwardly'. 35 The monument thus emphasises both physically through its placement, as well as textually, through the use of Proverbs, the self-perception of a community which placed its theological emphasis on the preaching and spreading of the Word. Most visually accessible to the congregation in the nave and relying on passages, in English, from Proverbs echoing the written works of John Dod has the effect of emphasising the centrality of the pulpit, making the Knightley tomb a player in the re-articulation of church space at the fringes of the mainstream of developing English protestant identity.

The relationship between materiality, space and text that the funerary monument provides can be invaluable to an understanding of how members of Early Modern parish communities experienced the doctrinal changes that marked the Reformation. Equally, it can shed further light on the flowering 'across the whole range of commemorative art' throughout the late sixteenth and early seventeenth century by providing an additional rationale behind a patron's choice of commemoration. ${ }^{36}$ Building on research into the social and spiritual function of the monument by Peter Sherlock, and by going beyond the academic discourse on the monument's role as a tool in familial and individual fashioning and self-

\footnotetext{
34 J. Fielding, 'Dod, John (1550-1645)', in Oxford Dictionary of National Biography, online edn, January 2008 (Oxford: Oxford University Press, 2004) <http://www.oxforddnb.com/view/article/7729> [accessed 1 August 2016]; Cleaver and Dod, p. 157.

35 Ibid., p. 185.

${ }^{36}$ Nigel Llewellyn, Funeral Monuments in Post-Reformation England (Cambridge: Cambridge University Press, 2000), p. 7.
} 
fashioning by such scholars as Nigel Llewellyn and Jennifer Woodward, the tomb can shed light on the way in which patrons sought equally to establish their legacy and lineage, while making a conscientious effort at endowing the church with markers of evangelical, and even puritan theology, ritual and devotion. ${ }^{37}$ As such, the funeral monument continued as a form of 'intrusion' into the church space, in which it coveted the gazes of the congregation, and actively participated in shaping the communal experience of a changing and often precarious religious climate. It equally sheds light on the playful nature with which Protestant patrons sought to develop new reading and writing practices, engaging actively in alteration, translation and appropriation, highlighted in particular by the enthusiastic continual use of the Latin language in biblical tomb inscriptions, a practice which falls in line with a more open attitude toward Latin scripture in contemporary publications such as the Preces Privatæ and state documents such as the Elizabethan Injunctions. Thus the reformation and postreformation monument corroborates Eamon Duffy's assertion of continuity in an understanding of 'the sacred character of Latin itself, as higher and holier than the vernacular.' ${ }^{38}$ The monument therefore contributed to one of the functions of the church as outlined by the Injunctions by ensuring that 'all parishioners' have continuous access to 'such comfortable places and sentences of Scripture as do set forth the mercy, benefits and goodness of Almighty God'. ${ }^{39}$ Katherine Willoughby thus, even in death continued her quest, as urged by reformer Augustine Bernher, to be the 'instrumente by the whiche hys holy name should be praysed, and his gospell propagated and spredde'. ${ }^{40}$

\footnotetext{
37 Jennifer Woodward, The Theatre of Death: The Ritual Management of Royal Funerals in Renaissance England 1570-1625 (Woodbridge: Boydell Press, 1997).

${ }^{38}$ Eamon Duffy, The Stripping of the Altars: Traditional Religion in England 1400-1580 (New Haven: Yale University Press, 1992), p. 218.

${ }^{39}$ Elizabethan Injunctions, 1559, pp. 335-48 (p. 339).

${ }^{40}$ Hugh Latimer, 27 sermons preached by the ryght Reuerende father in God and constant matir of lesus Christe, Maister Hugh Latimer [...], ed. by Augustine Bernher (London: John Day, 1562), sig. A6v.
} 


\section{Bibliography}

\section{Consulted Bible Texts:}

Biblia sacra vulgata, (Clementine), in drbo.org, <http://www.drbo.org/index.htm> [accessed 1 August 2016]

Douay-Rheims Bible + Challoner Notes, in drbo.org, <http://www.drbo.org/index.htm> [accessed 1 August 2016]

The Bible and holy scriptvres conteyned in the Olde and Newe Testament. Translated According to the Ebrue and Greeke, and conferred with the best translations in diuers langages. With moste profitable annotations vpon all the Lord places, and other things of great importance as may appeare in the Epistle to the Reader [The Geneva Bible] (Geneva: Rouland Hall, 1560)

The Byble in Englyshe that is to saye the content of all the holy scrypture, both of ye olde and newe testament, truly translatedafter the veryte of the Hebrue and Greke textes, by ye dylygentstudye of dyuerse excellent learned men, expert in the forsaydetonges [The Great Bible] (London: Rychard Grafton and Edward Whitchurch, 1539)

The. holi. Bible. [The Bishops' Bible] (London: Richard Jugge, 1568)

\section{All Other Texts:}

Becon, Thomas, The Castell of Comforte (London: John Day, 1549)

Bray, Gerald, Documents of the English Reformation, Library of Ecclesiastical History (Cambridge: James Clarke \& Co, 1994)

Bryant, Christopher G. A., and David Jary, eds., Anthony Giddens: Critical Assessments, 4 vols (London: Routledge, 1997) 
Bridges, John, The history and antiquities of Northamptonshire. Compiled from the manuscript collections of the Late Learned Antiquary John Bridges, Esq. By the Rev. Peter Whalley, 2 vols (Oxford: T. Payne, 1791)

Buttick, George Arthur, ed., The Interpreter's Bible: The Holy Scriptures in the King James and Revised Standard Versions with General Articles and Introduction, Exegesis, Exposition for Each Book of the Bible, 12 vols (New York: Abingdon Press, 1954)

Clay, Rev. William Keatinge, ed., Private Prayers, Put Forth by Authority during the Reign of Queen Elizabeth (Cambridge: Cambridge University Press, 1851)

Cleaver, Robert, John Dod, A briefe explanation of the whole booke of the Prouerbs of Salomon (London: Felix Kyngston, 1615)

Cummings, Brian, ed., The Book of Common Prayer: The Texts of 1549, 1559, and 1662 (Oxford: Oxford University Press, 2011)

Dickens, A. G., and Robert Parkyn, 'Robert Parkyn's Narrative of the Reformation', English Historical Review, 62.242 (1947), 58-83 <https://doi.org/10.1093/ehr/LXII.CCXLII.58> [accessed 9 January 2017]

Dod, John, Bathshebaes instructions to her sonne Lemuel containing a fruitfull and plaine exposition of the last chapter of the Prouerbs. Describing the duties of a great-man, and the vertures of a gracious woman. Penned by a godly and learned man, now with God. Perused, and published for the use of Gods church (London: John Beale, 1614)

Duffy, Eamon, The Stripping of the Altars: Traditional Religion in England 1400-1580 (New Haven: Yale University Press, 1992)

Fielding, J., 'Dod, John (1550-1645)', in Oxford Dictionary of National Biography, online edn, January 2008 (Oxford: Oxford University Press, 2004) <http://www.oxforddnb.com/ view/article/7729> [accessed 1 August 2016] 
Franklin-Harkrider, Melissa, Women, Reform and Community in Early Modern England: Katherine Willoughby, Duchess of Suffolk, and Lincolnshire's Godly Aristocracy, 1519-1580 (Woodbridge: Boydell Press, 2008)

Graves, Pamela, 'Social Space in the English Medieval Parish Church', in Anthony Giddens:

Critical Assessments, ed. by Christopher G. A. Bryant and David Jary, 4 vols (London: Routledge, 1997), IV, pp. 262-288

— The Form and Fabric of Belief: The Archaeology of Lay Experience in Medieval Norfolk and Devon, BAR British Series 311 (Oxford: Archaeopress, 2000)

Hasler, P. W., ed., The History of Parliament: the House of Commons 1558-1603, 3 vols (London: Her Majesty's Stationery Office, 1981)

Hicks, Michael, 'Willoughby family (per. c.1300-1523)', in Oxford Dictionary of National Biography, online edn, January 2008 (Oxford: Oxford University Press, 2004) <http:// www.oxforddnb.com/view/article/52801> [accessed 5 May 2016]

Hoak, Dale, ed., Tudor Political Culture (Cambridge: Cambridge University Press, 1995) Holles, Gervase, Lincolnshire Church Notes made by Gervase Holles A. D. 1634 to A. D. 1642, ed. by R. E. G. Cole (Lincoln: W. K. Morton \& Sons, 1911)

Kew, The National Archives, State Papers Domestic Edward VI, SP 10

King, Chris, Duncan Sayer, eds., The Archaeology of Post Medieval Religion (Woodbridge: Boydell Press, 2011)

Latimer, Hugh, 27 sermons preached by the ryght Reuerende father in God and constant matir of lesus Christe, Maister Hugh Latimer, as well such as in tymes past have bene printed, as certayne other commyng to our handes of late, whych were yet neuer set forth in print. Faithfully perused [and] allowed accordying to the order appoynted in the Quenes Maiesties iniunctions. 1. Hys sermon Ad clerum. 2. Hys fourth sermon vpon the plough. 3. Hys. 7. sermons before kyng Edward. 4 Hys sermon at Stamforde. 5. Hys last sermon before kyng Edward. 6. Hys. 7. sermons vpon the Lordes prayer. 7. Hys 
other. 9. sermons vpon certayne Gospels and Epistles, ed. by Augustine Bernher (London: John Day, 1562)

Lincoln, Lincolnshire Archives, 10-ANC/317/1

Llewellyn, Nigel, Funeral Monuments in Post-Reformation England (Cambridge: Cambridge University Press, 2000)

Newman, Christine M., 'Bellasis family (per. c.1500-1653)', in Oxford Dictionary of National Biography, online edn, January 2008 (Oxford: Oxford University Press, 2004) <http:// www.oxforddnb.com/view/article/71863> [accessed 1 August 2016]

Pettegree, Andrew, ed., The Reformation World (London: Routledge, 2000)

Pevsner, Nikolaus and John Harris, Lincolnshire, The Buildings of England (Harmondsworth: Penguin, 1964)

Pevsner, Nikolaus, Yorkshire: The North Riding, The Buildings of England (Harmondsworth: Penguin, 1966)

Phillippy, Patricia, “"Monumental Circles” and Material Culture in Early Modern England', Early Modern Women, 4 (2009), 139-147

Roffey, Simon, Chantry Chapels and Medieval Strategies for the Afterlife (Stroud: Tempus, 2008)

_- 'Romantic Anachronisms? Chantry Chapels in the 19th Century', in The Archaeology of Post Medieval Religion, ed. by Chris King and Duncan Sayer (Woodbridge: Boydell Press, 2011)

Ryrie, Alec, The Gospel and Henry VIII: Evangelicals in the Early English Reformation (Cambridge: Cambridge University Press, 2003) <https://doi.org/10.1017/ CB09780511496028> [accessed 9 January 2017]

Sherlock, Peter, Monuments and Memory in Early Modern England (Aldershot: Ashgate, 2008) 
Smith, Harry Cotton, The Town of Sir John Franklin: A History of Spilsby in Lincolnshire, with Notes on Eresby and Other Places Connected Therewith (Spilsby: The Spilsby Printing Company, 1892)

Spicer, Andrew, 'Architecture', in The Reformation World, ed. by Andrew Pettegree (London: Routledge, 2000), pp. 505-520

Terrien, Samuel, 'Job: Introduction', in The Interpreter's Bible: The Holy Scriptures in the King James and Revised Standard Versions with General Articles and Introduction, Exegesis, Exposition for Each Book of the Bible, ed. by George Arthur Buttick, 12 vols (New York: Abingdon Press, 1954), III, pp. 877-905

Tittler, Robert, 'Political Culture and the Built Environment of the English Country Town, c. 1540-1620', in Tudor Political Culture, ed. by Dale Hoak (Cambridge: Cambridge University Press, 1995), pp. 133-156

Tomlins, Thomas Edlyne, John Raithby, eds., The statutes at large, of England and of Great Britain: from Magna Carta to the union of the kingdoms of Great Britain and Ireland, 20 vols (London: G. Eyre and A. Strahan, 1811)

Whiting, Robert, The Reformation of the English Parish Church (Cambridge: Cambridge University Press, 2010)

Woodward, Jennifer, The Theatre of Death: The Ritual Management of Royal Funerals in Renaissance England 1570-1625 (Woodbridge: Boydell Press, 1997) 